\title{
Don Bebout
}

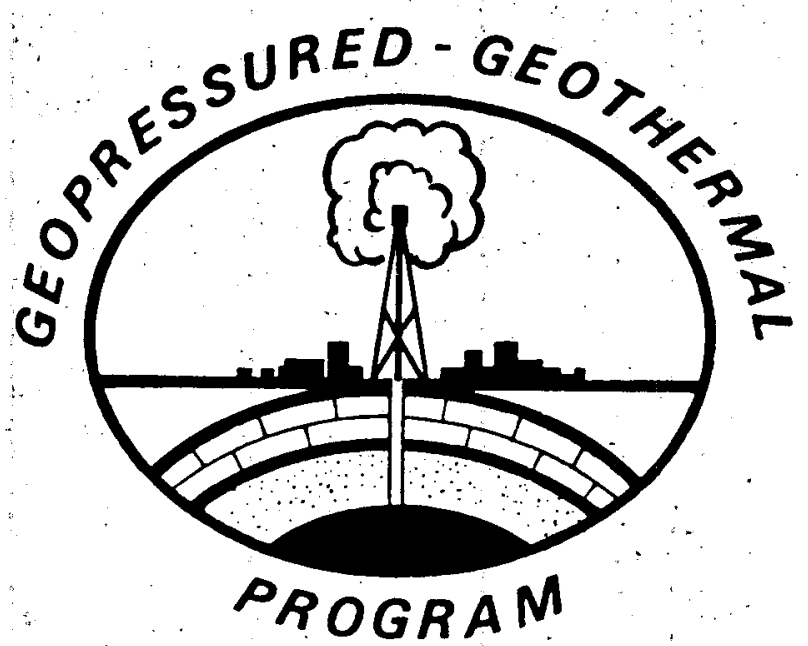

\section{TESTING GEOPRESSURED GEOTHERMAL RESERVOIRS IN EXISTING WELLS}

\author{
U.S. DEPARTMENT OF ENERGY \\ CONTRACT NO. DE-ACO8-890ET27081
}

DETAILED COMPLETION PROGNOSIS

FOR GEOPRESSURED - GEOTHERMAL WELL OF OPPORTUNITY

PROSPECT 非 1

CLOVIS A. KENNEDY NO. 1 WELL

EATON OPERATING COMPANY, INC.

3100 EDLOE, SUITE 205

HOUSTON, TEXAS 77027

713-627-9764 


\section{DISCLAIMER}

This report was prepared as an account of work sponsored by an agency of the United States Government. Neither the United States Government nor any agency Thereof, nor any of their employees, makes any warranty, express or implied, or assumes any legal liability or responsibility for the accuracy, completeness, or usefulness of any information, apparatus, product, or process disclosed, or represents that its use would not infringe privately owned rights. Reference herein to any specific commercial product, process, or service by trade name, trademark, manufacturer, or otherwise does not necessarily constitute or imply its endorsement, recommendation, or favoring by the United States Government or any agency thereof. The views and opinions of authors expressed herein do not necessarily state or reflect those of the United States Government or any agency thereof. 


\section{DISCLAIMER}

Portions of this document may be illegible in electronic image products. Images are produced from the best available original document. 


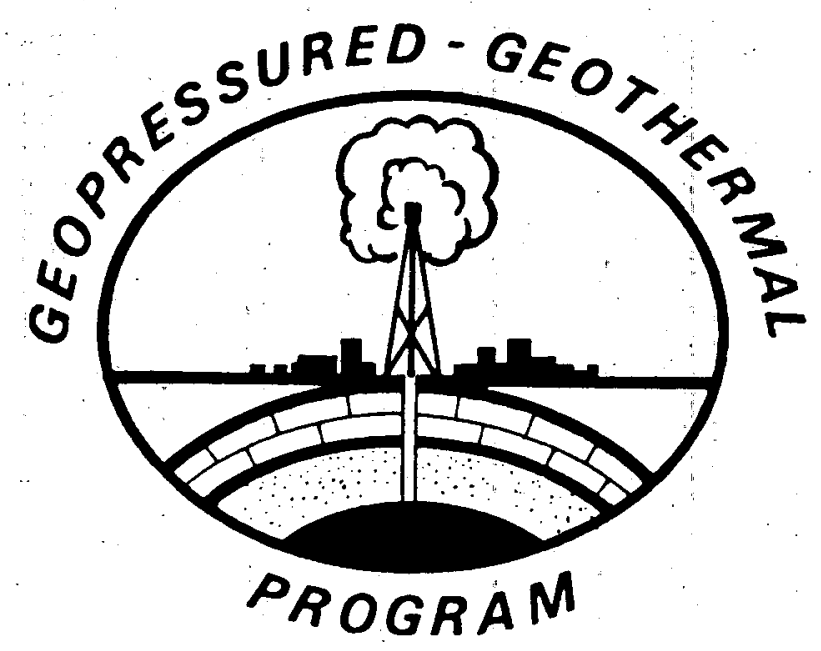

\title{
TESTING GEOPRESSURED GEOTHERMAL RESERVOIRS IN EXISTING WELLS
}

\author{
U.S. DEPARTMENT OF ENERGY \\ CONTRACT NO. DE-ACO8-80ET27081 \\ DETAILED COMPLETION PROGNOSIS \\ FOR GEOPRESSURED - GEOTHERMAL WELL OF OPPORTUNITY \\ PROSPECT 非
}

CLOVIS A. KENNEDY NO. 1 WELL

EATON OPERATING COMPANY, INC.

3100 EDLOE, SUITE 205

HOUSTON, TEXAS 77027

713-627-9764 
Apri1 3, 1980

Mr. R. T. Stearns

Engineering and Energy Applications Branch

United States Department of Energy

Nevada Operations

Las Vegas, Nevada 89114

Re: IMC Exploration Company

Clovis_A. Kennedy 非 1 We11

Section 32 T1OS R2E

Vermilion Parish, Louisiana

Dear Mr. Stearns:

We are recommending that subject well be acquired from IMC Exploration Company and tested as a $\mathrm{GEO}^{2}$ well of opportunity. $\mathrm{A}$ detailed completion, testing and cost estimate is included with this recommendation.

Agreements with IMC, as operator, and the landowners have been proposed and accepted, subject to DOE approval. Agreements with the nine landowners are in the mail for their signing. The IMC agreement will be signed once a11 1 andowners have signified their agreement in writing.

The Clovis A. Kennedy Well was formerly a well which was recently shut in as uneconomical to produce. It is equipped with $5-1 / 2$ " 23.5 非 $\mathrm{p}-110$ casing to total depth of $16,180^{\prime}, 2-3 / 8^{\prime \prime}$ tubing, packer and a 15,000 IMC has agreed to sell the Kennedy Well and a nearby salt water disposal well to Eaton. The consideration for this sale will be Eaton's assumption of plugging and abandonment liability for both wel1 bores. IMC will retain ownership of the X-mas tree and the tubing until abandonment if they so choose.

It is doubtful the $5-1 / 2^{\prime \prime}$ casing can be recovered economically. However, we would make an evaluation attempt at recovery prior to plugging.

Estimated costs for workover, testing and plugging are summarized as follows:

Estimated cost to clean out, complete and plug Kennedy Well

$\$ 648,000$

Estimated cost to recomplete and plug salt water disposal we11.

$$
55,000
$$

Estimated cost to conduct test program

407,000

EOC we11 test fee

112,500

Tota1 Estimated Cost

$\$ 1,222,500$

Eaton Industries of Houston, Inc. 
Mr. R. T. Stearns

Apri1 3, 1980

Page 2

The Kennedy Well has a Bol Mex F-1 water sand present from 15,826 to 15,942 feet behind the $5-1 / 2 "$ casing which apparently meets all parameters for a successful $G E O^{2}$ test. The top of the water sand $(F-1)$ is some seven hundred feet below the present producing perforations which will be squeezed off.

We believe this is a good $\mathrm{GEO}^{2}$ prospect which can be recompleted, tested and plugged with considerable savings as compared to taking over a new 1 y drilled well.

Yours truly,

EATON OPERATING COMPANY

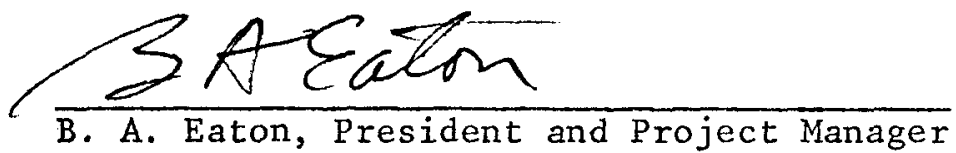

$$
\text { cc: Messrs. } \begin{aligned}
\text { Clifton Carwile } \\
\text { Bennie DiBona } \\
\text { Robert Holliday } \\
\text { Keith Westhusing }
\end{aligned}
$$


Eaton Industries of Houston, Inc. Eaton Operating Co.. Inc. 3100 Edloo 


\title{
TESTING GEOPRESSURED - GEOTHERMAL
}

RESERVOIRS IN EXISTING WELLS

DETAILED COMPLETION PROGNOSIS

FOR GEOPRESSURED - GEOTHERMAL WELL OF OPPORTUNITY

PROSPECT 非 1

CLOVIS A. KENNEDY NO. 1 WELL

\author{
EATON OPERATING COMPANY \\ 3100 EDLOE, SUITE 205 \\ HOUSTON, TEXAS 77027 \\ APRIL 3, 1980 \\ PREPARED FOR THE DEPARTMENT OF ENERGY \\ DIVISION OF GEOTHERMAL ENERGY \\ UNDER CONTRACT NO. DE-AC08-80ET27081
}


Introduction

$\underline{\text { Page }}$

Geology

1

Workover Procedure For Test We1l

2

Workover Procedure For Disposal We11

9

We11 Test Procedure

Fluid Sampling Procedure

Data Acquisition System

Cost Analysis

Environmental Information Checklist

\section{LIST OF FIGURES}

\section{FIGURE}

1 ISF Sonic Log of Target Intermal

2 ISF Log of Bo1-Mex Sand Series

3 Structure Map, Bol-Mex F Sand

4 Schematic of Test We 11

5 Schematic of Test X-Mas Tree

6 Schematic of Disposal Well 15

7 Surface Test Schematic

\section{LIST OF TABLES}

TABLE

I Total Estimated Cost To Complete Test and Plug

II Estimated Cost To Workover and Plug IMC Clovis A. Kennedy We11 非 1

III Estimated Cost To Workover and Plug Disposal Well

IV Estimated Cost To Test We11

Eaton Industries of Houston, Inc. 


\section{GEOLOGY}

The subsurface geology of the zone of interest has been developed primarily through electric $\log$ and drill cuttings analysis. Seismic data in the area for the zone of interest are virtually non-existent.

The target sand is the Bo1 Mex "F1" which occurs at a depth of 15,826 to 15,942 feet $(\mathrm{KB}$ ) in the C.A. Kennedy 非 1 we11 (See ISF/ Sonic $\log$ in Figure 1 ). The Bol Mex series of sands extends from 15,215 to 16,084 feet $(K B)$ as shown in the ISF $\log$ in Figure 2 .

A structure map of the top of the target Bol-Mex "F" sand, is presented in Figure 3. As indicated by this map, the prospect area is bounded by growth faults and consists of more than 1000 acres. The test we11 is located between two anticlinal structures, near the base of the intervening trough. The fault nearest the test we11 occurs about 1300 feet to the south.

Within the reservoir, (as defined by the growth faults) the Bo1Mex "F1" sand ranges in gross thickness between 20 to 135 feet. It appears to thin significantly in the northeastern sector of the fault block. However, within about 3,500 feet, the minimum observed thickness is 85 feet. Gross sand thicknesses determined from logs of wells within one mile of the No. 1 C.A. Kennedy well are presented as follows:

WELL GROSS SAND THICKNESS, ft.

Wrightman Inv.

No.1 C. A. Kennedy, et al

Wrightman Inv.

No. 3 C. A. Kennedy

McCu1loch 0 il

No. 1 E. H. $\mathrm{McCa} 11$, et $\mathrm{a}$

IMC, Inc.

Hayes No. 1

Eaton Industries of Houston, Inc.

Eaton Operating Co., Inc.

3100 Edloe

Houston, Texas 77027

(713) 627.9764 


\section{RESERVOIR CHARACTERISTICS}

The predicted reservoir characteristics of the Bol Mex "Fl" sand and

the basis for their determination are presented as follows:

-Net Sand Thickness

The net sand thickness was determined to be $94^{\prime}$ feet based upon analysis of the SP log. Excursions of the SP curve toward the shale base line which represent shale streaks of at least 1 foot were subtracted from the gross sand thickness to obtain this value.

-Porosity

Porosities calculated from the sonic log range from $15 \%$ to $32 \%$ and average $22 \%$. A matrix velocity of $17,500 \mathrm{ft} / \mathrm{sec}$ and a $\Delta t$ for the shale of $100 \mathrm{micro-}$ seconds/ft. were assumed. The porosity distribution is as follows:

\section{Gross \\ Interval}

$15,826-896$

15-896-910

$15,910-918$

$15,918-924$

$15,924-942$

$15,826-942$

\author{
Net Sand \\ Thickness, ft.
}

59

9

6

5

15

94

\section{Average \\ Porosity, \%}

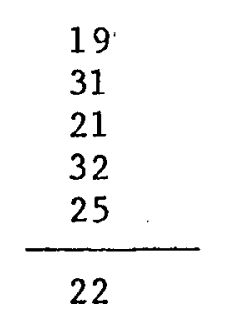

\section{-Pressure}

The average pressure in the target sand is estimated to be about 13,590 psi based upon a measurement of 13,000 psi initial pressure in the Bol Mex " $A$ " sand (depth of $15,230^{\prime}$ ) and a gradient of about $.9 \mathrm{psi} / \mathrm{ft}$ (17.2k/gal mud), for the interval below this sand.

\section{-Temperature}

The average sand temperature is estimated to be about $278^{\circ} \mathrm{F}$ based upon a BHT of $274^{\circ} \mathrm{F}$ a $16,287^{\prime}$ measured after circulation had been stopped for 6 hours. Ten degrees, or about $1 / 3$ of the AAPG correction, was added to the BHT to obtain this value. 
-Salinity

Calculated salinity is about 100,000 ppm based upon analysis of SP logs, using corrected values of $\mathrm{SP}$ and a measured $\mathrm{R}_{\mathrm{mf}}$ of $.30 \mathrm{mv}$ at $73^{\circ} \mathrm{F}$.

Eaton Industries of Houston, Inc.

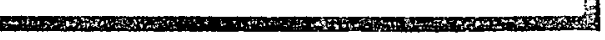

Eaton Operating Co., Inc.

3100 Edloe

Houston, Texas 77027

(713) 627.9764 


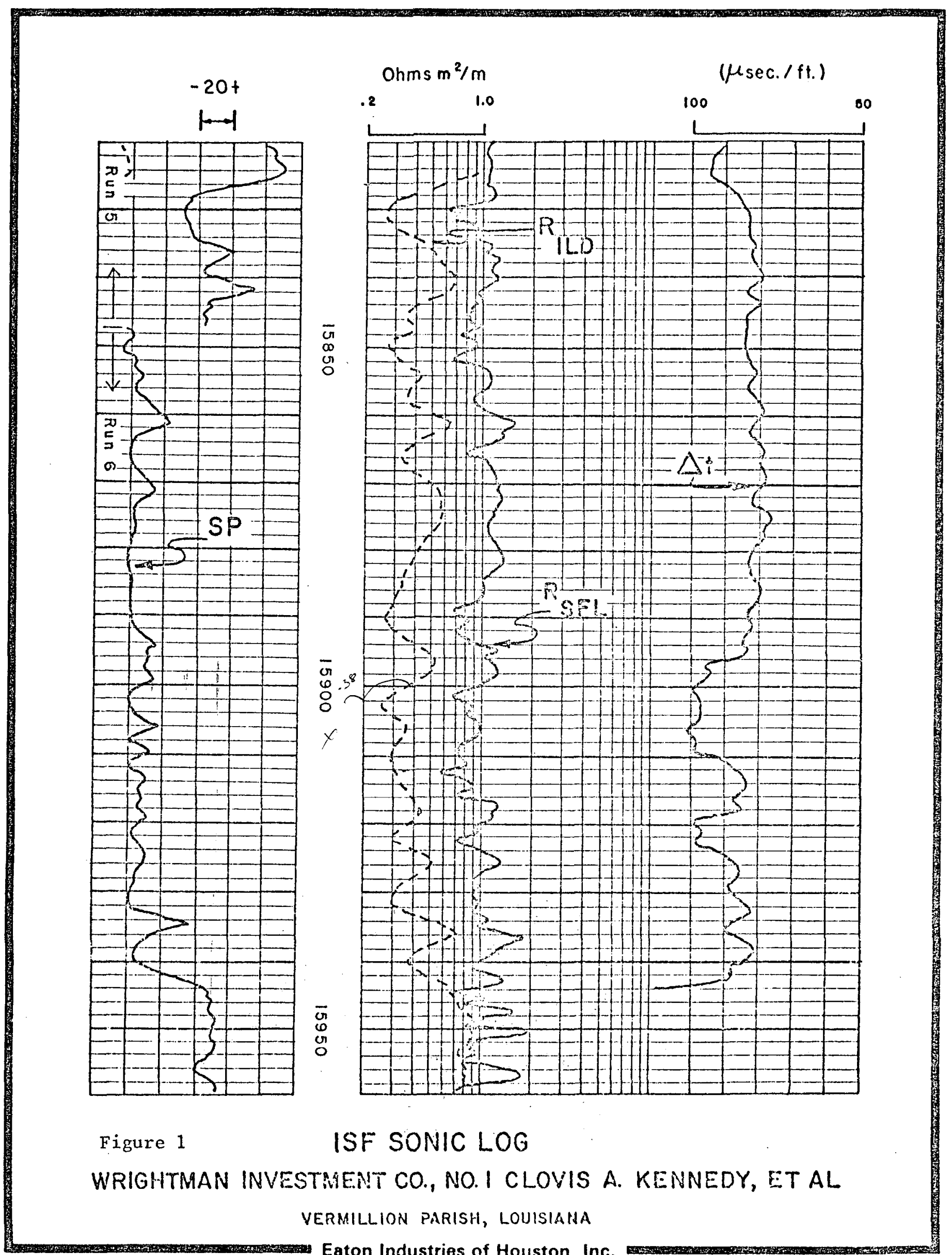




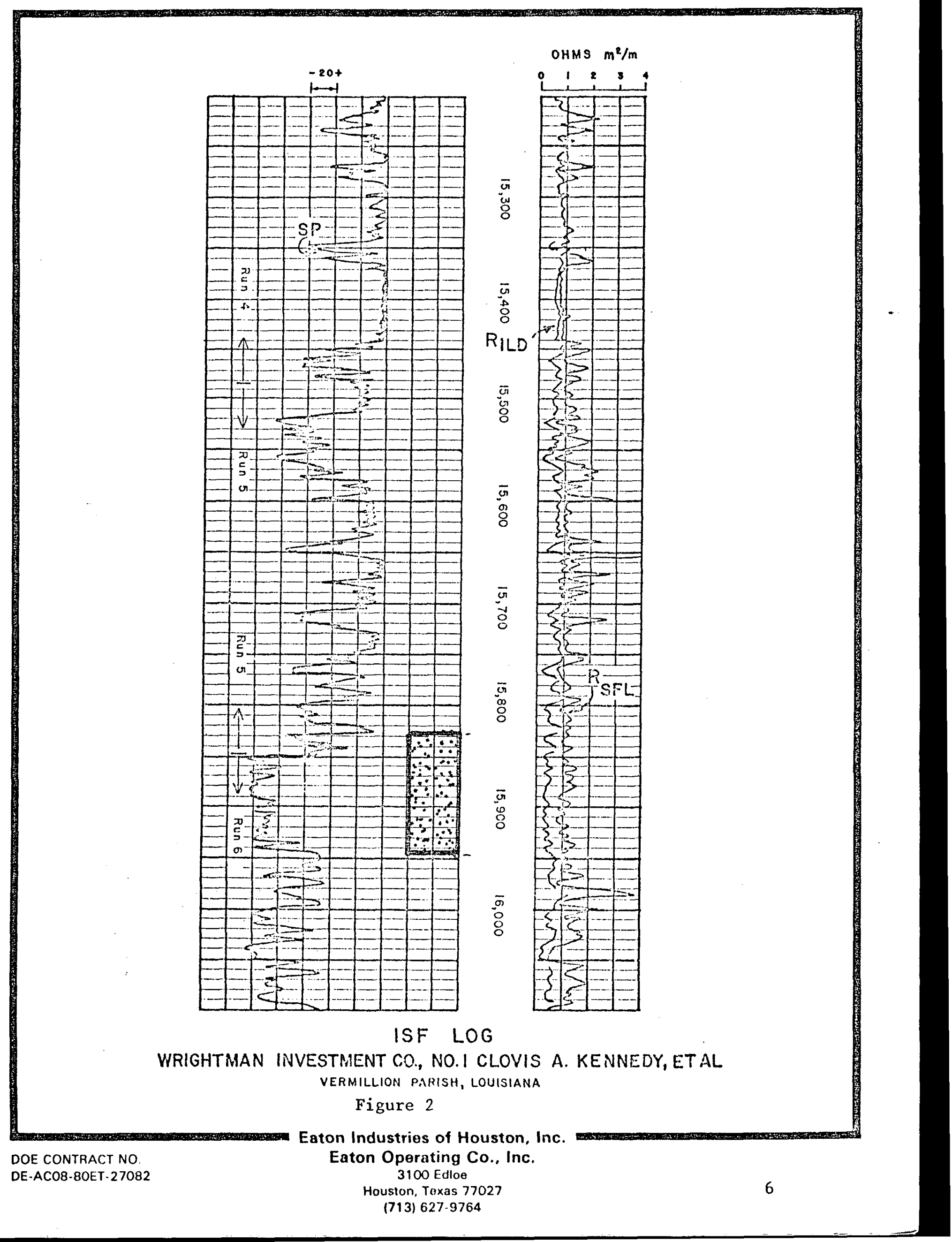




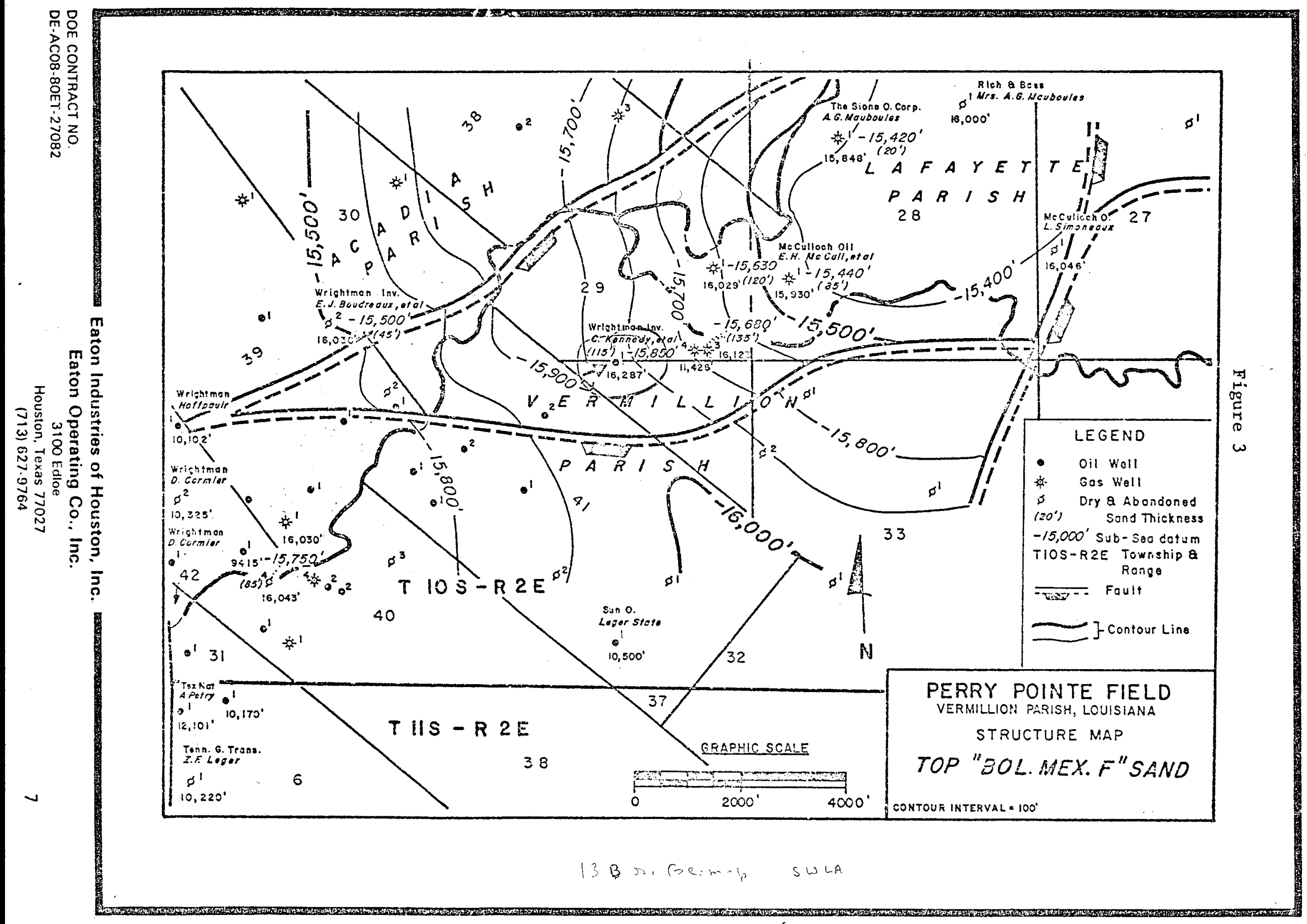




\section{TABLE I}

TOTAL ESTIMATED COST

TO COMPLETE, TEST AND PLUG

\section{IMC CLOVIS A. KENNEDY WELL \#1}

Workover and Plug Test We11

Test Operations

Workover and Plug Salt Water Disposal Well

EOC We11 Test Fee

Tota1 Estimated Cost
$\$ \quad 648,000$

407,000

55,000

112,500

$\$ 1,222,500$

Eaton Industries of Houston, Inc. 


\section{WORKOVER PROCEDURE FOR TEST WELL}

\section{PRESENT MECHANICAL CONDITION}

Figure 4 illustrates the actual present mechanical condition of the well. The well has a shut in tubing pressure of $2,800 \mathrm{psi}$ and a pressure of $5,200 \mathrm{psi}$ on the 5-1/2" casing. Tha casing pressure indicates either parted tubing or a tubing leak. The packer fluid is a $17.4 \mathrm{ppg}$ mud. Some amount of fishing will most likely be required to clean out the well.

\section{WORKOVER OPERATION}

1. Move in workover rig of appropriate size and prepare $300 \mathrm{bb} 1$ of 17 ppg liquid mud. Attempt to bleed pressure off 5-1/2" casing while pumping mud into tubing. Lubricate mud into casing if necessary to kill well.

2. Nipple down $\mathrm{X}$-mas tree and nipple up $10,000 \mathrm{psi} B O P^{\prime}$ s and choke manifold.

3. Attempt to pull tubing out of hole. If tubing will not come free, run free point and cut and recover free tubing. Wash over remaining tubing and cut and recover in several sections. A rental string of 2-7/8" drill pipe will be used as the fishing string. (The tubing recovered from the well and sections of the X-mas tree will be reconditioned, if possible, and used for the testing program. Otherwise tubing and $\mathrm{X}$-mas tree valves will be rented.)

4. Mill over and recover packer or push same to bottom.

5. Go in hole with squeeze tool and squeeze perforation 15,216-15,238' with 200 sacks of cement.

6. Drill out cement and go in hole with squeeze tooi. Displace work string with $9.0 \mathrm{ppg}$ salt water close squeeze tool and check if perforations are leaking. If necessary, squeeze again until perforations are sealed off.

7. Run gamma ray, cement bond log from plug back depth to top of cement in 5-1/2" casing. Run casing inspection $10 \mathrm{~g}$ from PBD to surface. Run hydrocarbon evaluation $\log$ from bottom to 15,000'. Block squeeze test zone if necessary.

8. Displace mud with $9.8 \mathrm{ppg}$ salt water and lay down work string.

9. Go in hole with $2-3 / 8^{\prime \prime}$ tubing and hang same at $15,800^{\prime}$. 
10. Insta11 test tree (see Figure 5) and make wire line run with dummy tool to check for perforating gun.

11. Move out workover rig.

12. Rig up through-tubing perforating gun with high pressure lubricator go in hole and perforate $15,850-15,945^{\prime}$. This will take five runs.

13. Commence production tests.

\section{PLUG \& ABANDONMENT OPERATION}

1. After production tests are completed, kill well with mud by pumping down tubing and circulating up annulus.

2. Move in workover rig.

3. Nipple down test tree and nipple up BOPS.

4. Pull tubing string out of hole. Set cement retainer at $15,150^{\prime}$ and squeeze perforations with 200 sacks of cement. Spot 50 sacks of cement on top of retainer.

5. Run free point on $5-1 / 2$ " casing and cut casing at free point and recover same, if practical.

6. Spot cement plug from $100^{\prime}$ below cut point to $200^{\prime}$ above cut casing.

7. Run free point on $9-5 / 8^{\prime \prime}$ casing and cut casing at free point and recover same.

8. Set cement retainer at $2,900^{\prime} \pm$ and pump 200 sacks of cement below retainer and spot 100 sacks of cement on top of retainer.

9. Spot 100 sacks of cement from $100^{\prime}$ below ground to surface.

10. Cut $13-3 / 8^{\prime \prime}$ casing and $20^{\prime \prime}$ pipe and weld $1 / 4^{\prime \prime}$ plate on top.

11. Move out rig and restore location.

DE-AC08-80ET-27082
Eaton Industries of Houston, Inc.

Eaton Operating Co.. Inc. 3100 Edloe

Houston, Texas 77027

(713) $627-9764$ 


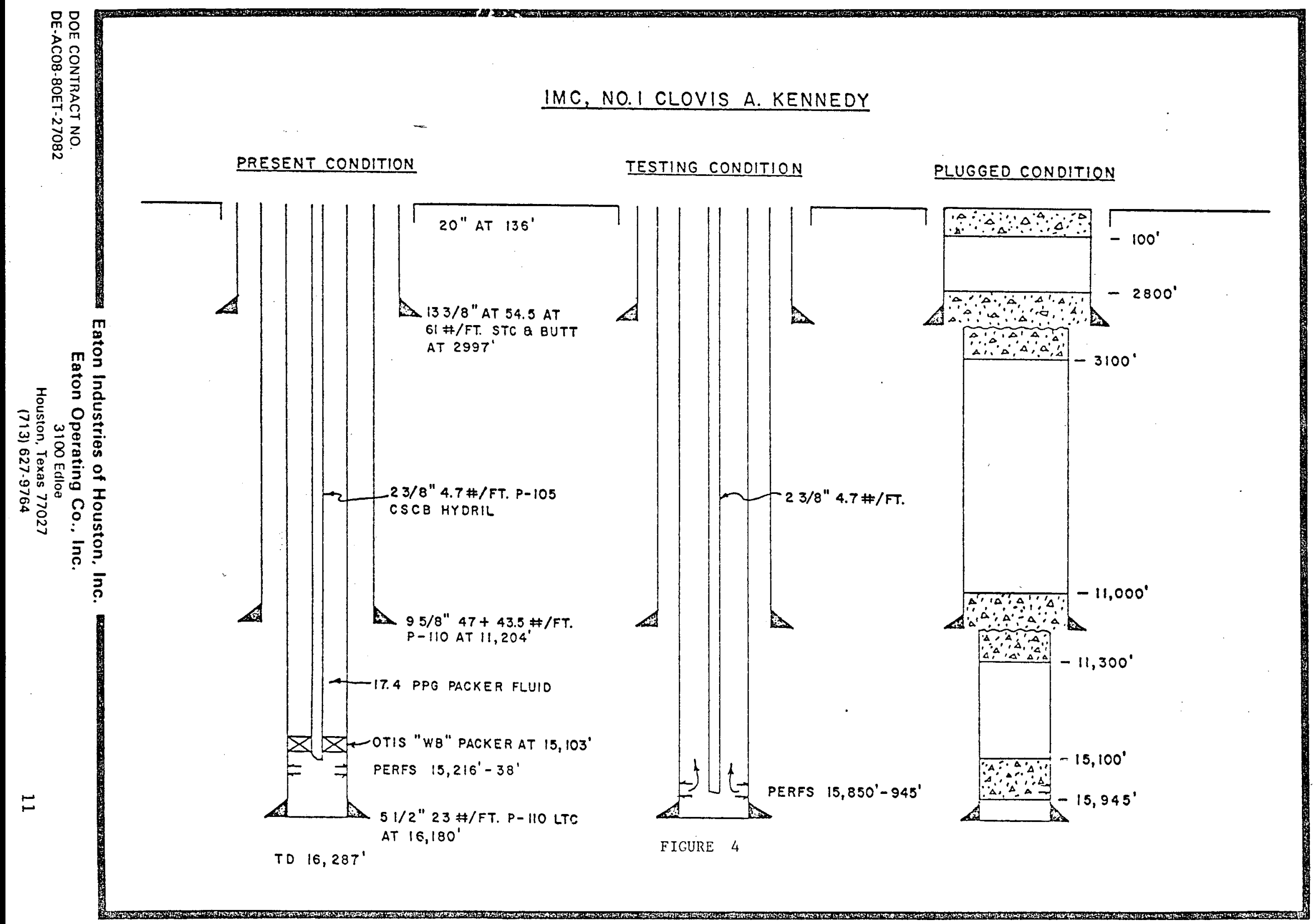




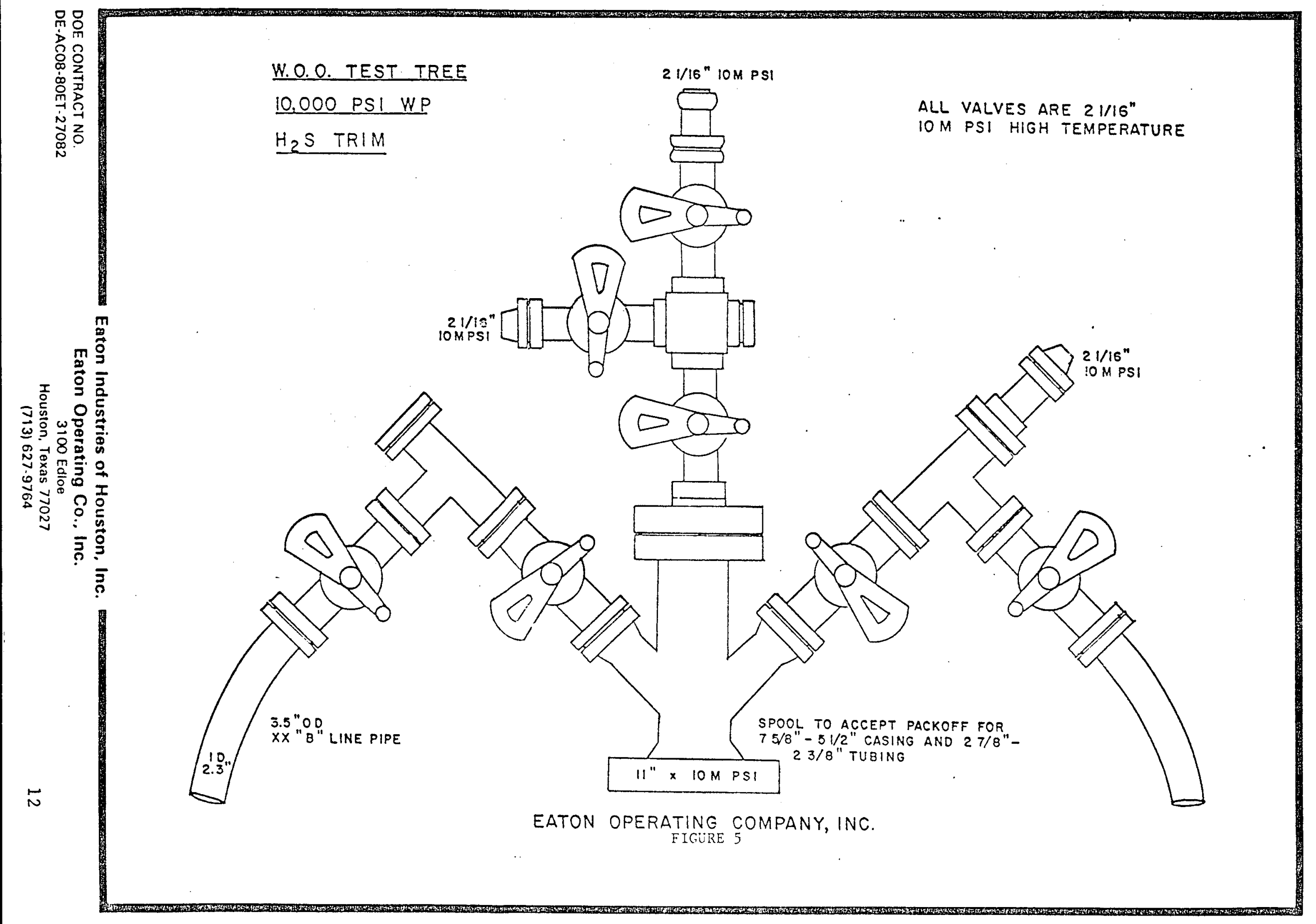




\section{TABLE II}

\section{ESTIMATED COST}

\section{TO WORKOVER AND PLUG}

IMC CLOVIS A. KENNEDY WELL 非 1

1. Landowners Fee

2. Location Expense \& Clean Up

3. Rig (30 Days + Moving Costs)

4. Mud - Chemicals

5. Cementing

6. Electric Logging \& Perforating

7. Contract Services \& Fishing

8. Too1 \& Equipment Rental

9. Professional Services

10. Other Workover Costs

(Bits, welding, trucking, fuel, packer, nipples, wellhead modification, communication, acid, nitrogen)
$\$ 35,000$

25,200

170,000

33,500

17,000

60,000

55,000

46,300

40,000

50,000

30,000

56,000

30,000

$\$ \underline{648,000}$

Total

Eaton Industries of Houston, Inc. 


\section{PRESENT MECHANICAL CONDITION}

Figure 6, illustrates the actual mechanical condition of the disposal well. The operator was disposing approximately 1,300 barrels of water per day through $20^{\prime}$ of perforations prior to termination of the disposal operation. Our plan is to open additional perforations and run larger tubing in the well to accommodate high disposal rates.

\section{WORKOVER OPERATION}

1. Move in workover rig and fill tubing and casing with $9.5 \mathrm{ppg}$ salt water.

2. Nipple down $X$-mas tree and nipple up blow out preventors.

3. Pull tubing and packer out of hole.

4. Go in hole with bit and circulate out any sand or debris from bottom. Pull out of hole.

5. Run casing perforating gun in the hole and perforate 2760-2830'.

6. Run packer and $3-1 / 2^{\prime \prime}$ tubing in hole and set packer at about $2700^{\prime}$.

7. Hook up pump and check for disposal capacity of 10,000 BWPD (292 GPM). If disposal capacity is satisfactory, hang tubing and nipple down BOPS.

8. Instal1 $\mathrm{X}$-mas tree and move rig off.

9. Proceed with we11 testing.

\section{PLUG \& ABANDONMENT OPERATION}

1. Move in rig and fill tubing with $9.5 \mathrm{ppg}$ salt water.

2. Nipple down $X$-mas tree and nipple up BOPS.

3. Pull tubing and packer out of hole and go in hole with cement retainer. Set retainer at $2500^{\prime} \pm$ and pump 200 sacks of cement below retainer and spot 25 sacks of cement above retainer.

4. Spot 30 sacks of cement from $200^{\prime}$ below ground level to surface.

5. Cut 5-1/2" casing and weld metal plate on top.

6. Move out rig and clean up location.

Eaton Industries of Houston, inc.

\section{Eaton Operating Co., Inc.} 3100 Edloe 


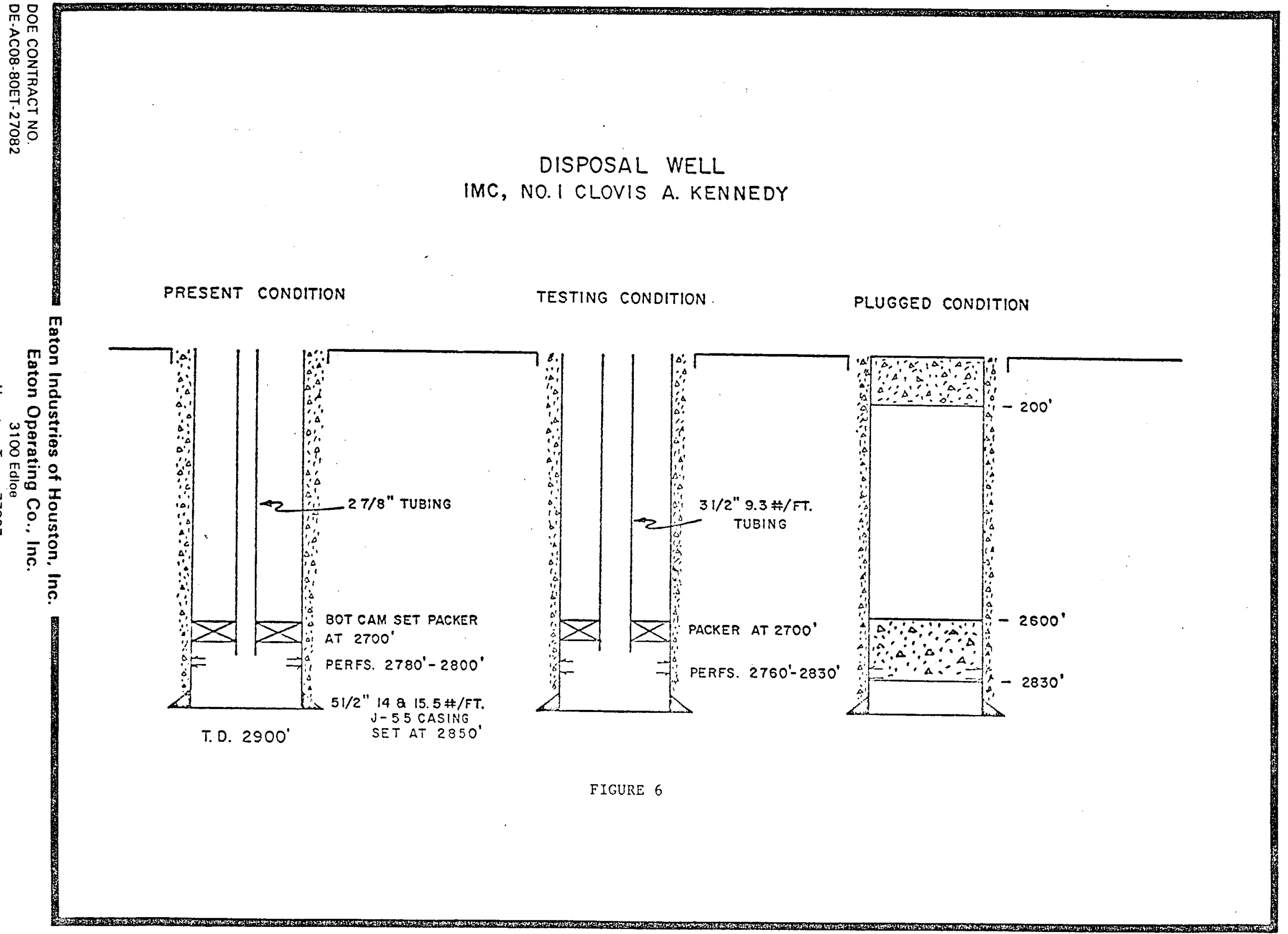


TABLE III

ESTIMATED COST TO WORKOVER

AND PLUG DISPOSAL WELL

IMC CLOVIS A. KENNEDY WELL 非

1. Location Expense \& Clean Up

$\$ 1,500$

2. Rig (4 Days a 5,000/Day)

20,000

3. Cementing

4,900

4. Perforating

10,000

5. Contract Services

3,000

6. Too1 \& Equipment Renta1

6,000

7. Professional Services

2,000

8. Other Workover Costs

3,000

9. Unanticipated Workover Costs

3,000 ( $10 \%$ of Above)

10. Overhead and $G \& A$

1,600

Total

$\$ 55,000$

Eaton Industries of Houston, Inc. 


\section{WELL TEST PROCEDURE}

IMC CLOVIS A. KENNEDY WELL NO. 1

Surface test equipment will be installed as shown on Figure 7 . Both the tubing and casing will be full of salt water.

\section{TEST OPERATION}

1. When well is ready to flow, run Hewlett Packard pressure gauge and temperature gauge to bottom of tubing at 15,850'. Obtain pressure and temperature gradient data every $1000^{\prime}$ while going in hole. After reaching bottom, wait for pressure and temperature to stabilize. Make sure surface pressure and surface temperature recorders are working.

2. Flow well at 2400 BPD rate for 48 hours. Separator will be bypassed until at least one annular volume ( 250 BBLS) has flowed out of the well and sand production has stopped.

3. Shut well in for 96 hours or until build up of reservoir pressure is complete.

4. Pull Hewlett Packard pressure gauge out of hole and run bottom hole fluid sampler.

5. Produce 1 to 5 barrels of fluid and take sample of "fresh" fluid at bottom. Pull out of hole with sampler and run Hewlett Packard gauge back in well.

6. Open well up slowly to a rate of 5,000 BFPD over a 2 minute period. Bypass sand production to pit again as necessary. Flow well for 48 hours.

7. Increase flow rate to 10,000 BFPD for 24 hours.

8. Open wel1 up to maximum flow rate for 12 hours. The maximum flow rate for this well is expected to be 12,500 BFPD.

9. Shut well in for reservoir pressure build up analysis. The build up period may take about 8 days and during this time the surface production equipment will be disconnected and removed from the location.

10. A second bottom hole fluid sample will be taken at the end of the build up period.

The entire testing operation is expected to last approximately 21 days.

Eaton Industries of Houston, Inc. 
The procedures above may be altered as necessary to obtain the desired data.

Data collection points are indicated on figure 7 by circled letters and are listed below.

\section{DATA POINT}

A.

B.

C.

D.

E.

F.

G.

H.

I.

J.

$\mathrm{K}$.

L.

M.

\section{DESCRIPTION}

Bottom Hole Pressure and Temperature and Fluid Sample

Surface Pressure Recorder and Dead Weight Tester

Fluid Flow Meter

Fluid Flowing Temperature

Primary Fluid Sampling Line

Separator Pressure

Separator Temperature

Gas Meter

Gas Sample Point

Separator Water Sample Point

Fluid Flow Meters

Disposal We11

Surface Pressure.

Disposal We11

Bottom Hole Pressure 


\section{FLUID SAMPLING PROCEDURE}

1. When the test schedule is known, advance phone calls will be made to the following organizations to alert them should they desire to take their own samples.

- McNeese State University

- USGS - Menlo Park \& Bay St. Louis

- University of Texas

- L.S.U.

A11 third party sampling must be approved and supervised by the Eaton Engineer in charge to insure proper safety and operational procedures. IGT will maintain records and follow up on comparison of results.

2. When the well has flowed at 2400 BPD for several hours after bottoms up (step 2 of operating procedure), begin taking brine and gas samples. Analyze for time sensitive chemistry in the IGT field laboratory on location. Less critical analyses will be performed on samples sent back to the IGT - Chicago laboratory. Samples for radioactivity analysis will be provided to the USGS. High pressure samples will be flashed to atmoshperic pressure at location for gas/water ratio determination and two samples each of brine and gas will be taken at separator pressure for laboratory analysis.

3. During the 96 hour build up, surface lines will be examined for scale formation and examples of any scale found will be shipped to IGT for analysis.

4. Take two bottom hole samples at end of build up period. A few barrels of brine will be flowed so that the samples are fresh reservoir brine. Ship to IGT - Chicago for analysis.

5. During the stepwise increases in flow rate, sample collection and analysis at each rate will be as follows:

a. At least twice daily, collect wellhead pressure samples and flash to determine gas $/ \mathrm{H}_{2} \mathrm{O}$ ratio until it is clear that consistent and more accurate data is being obtained from the separator.

b. Perform daily on site analyses of samples from the separator consistent with the McNeese State University recommended procedures. 
c. Daily, collect samples from the separator gas and liquid output for subsequent $1 \mathrm{ab}$ analysis consistent with the Mclieese State University recommended procedures.

d. If IGT's field gas chromatograph and $\mathrm{CO}_{2}$ instrumentation are operational, perform field gas analysis of samples collected at several different separator operating pressures. Consistency of gas composition from the well will be checked by daily performance of the same analyses on gas obtained by flashing wellhead pressure samples.

6. During the last day of flow through the separator, additional separator pressure gas and liquid samples will be collected and retained up to one year for future analyses to resolve unanticipated issues. A few gallons of raw and acidified brine will also be stored at atmospheric pressure.

7. During disassembly of the testing equipment, it will be examined for any evidence of scale or corrosion. Observations will be documented and samples of any scale found will be shippped to IGT for analysis.

8. Take two final bottom hole samples at end of final build up to moving off location. Flow a few barrels first to insure that sample is fresh reservoir fluid.

DOE CONTRACT NO.

DE-AC08-80ET-27082
Eaton Industries of Houston, Inc.

Eaton Operating Co.. Inc. 3100 Edloe

Houston, Texas 77027

(713) $627-9764$ 


\section{DATA ACQUISITION SYSTEM}

IGT is now constructing the mobile trailer for use on the Wells of Opportunity program. The front part of the trailer will be the mobile chemical laboratory, the center will be the work area and storage area and the last part will be the electonic data gathering area.

The data acquisitions system inside the trailer will consist of six channels of strip chart recorders, a multichannel digital data logger, tape drive and small computer. The digital components will interface with each other via an IEEE-488 bus. Analog signals from the surface pressure and temperature transducers will all be recorded on digital tape and up to 6 of the pressures and temperatures will be simultaneously displayed on the strip chart recorder. If the digital data system from the service company that provides the bottom hole pressure gauges is compatible with the IEEE-488 interface bus then the digital bottom hole pressures will also be recorded on the IGT digital data tapes.

The mini computer will be used to edit and interpret the digital data and to sometimes control the data logger. It can also be used to transmit data via telephone to host computers or networks if a telephone is available. Some analysis of the data may be performed on location. The data tapes will be further reduced and the results reported after anlysis by the IGT computer in Chicago.

Eaton Industries of Houston, Inc. Eston Operating Co.. Inc. 3100 Edloo

Houston, Texas 77027

(713) 627.9764 
IMC CLOVIS A. KENNEDY WELL 非

1. Test Equipment Service Rental

2. Flow Loops \& Manifolding

3. Wire Line Unit With Mast \& Lubricator

4. Lighting \& Power

5. Contract Labor

6. Corrosion Inhibitor Service

7. Supervision

8. Contract Sampling \& Analysis (IGT)

9. Other testing Costs

10. Unanticipated Testing Costs ( $10 \%$ of Above)

11. Overhead and $G \& A$

Tota1
$\$ 60,000$

15,000

105,000

15,000

25,000

10,000

20,000

80,000

30,000

36,000

11,000

$\$ 407,000$

Eaton Industries of Houston, Inc. 


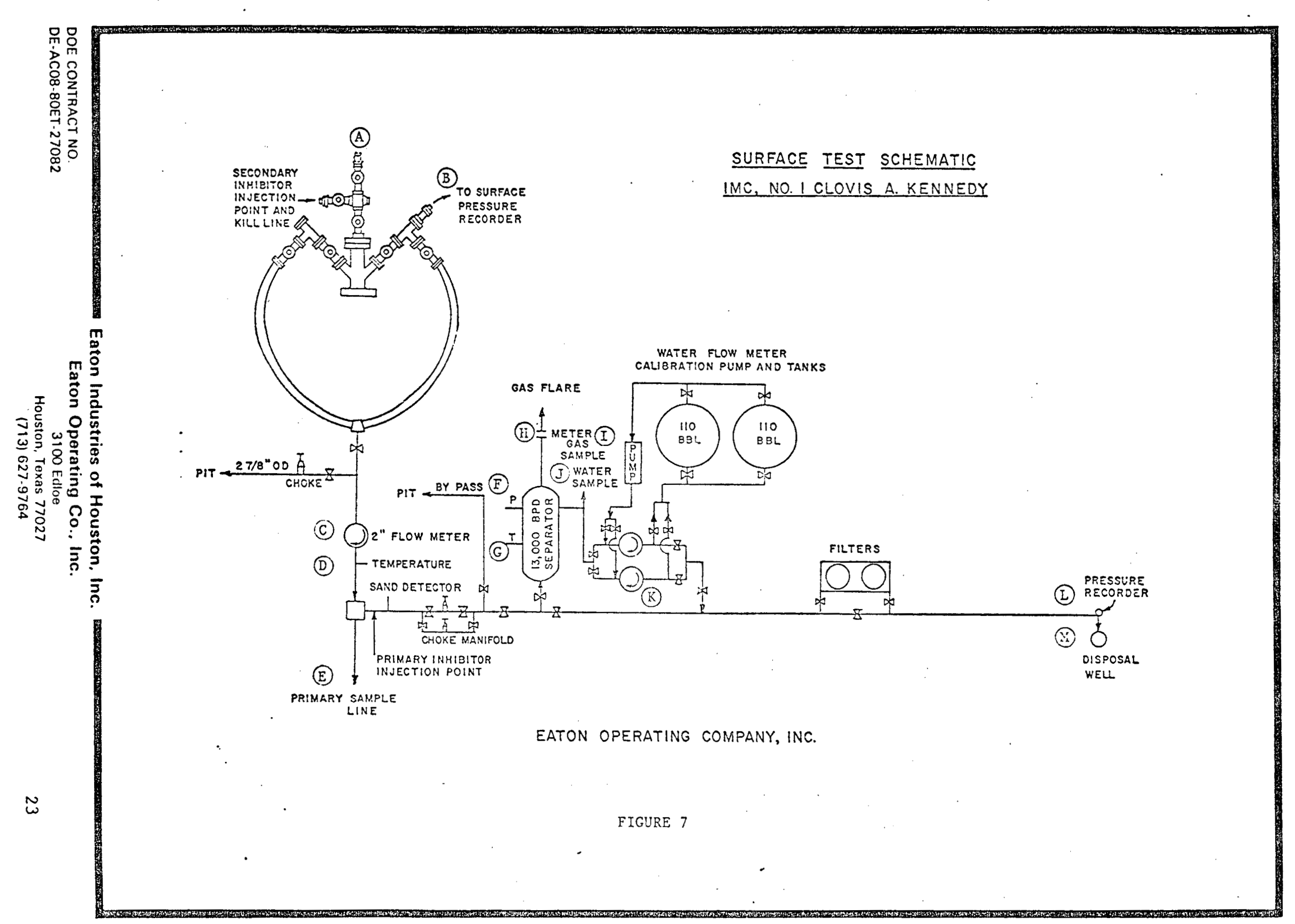


COST ANALYSIS

ESTIMATED COST VS. RECORDED COST

We11 Name IMC Clovis A. Kennedy We11 No. 1

Field or Prospect Perry Point Field

\begin{tabular}{lccc} 
& LEDGER & ORIGINAL & \\
CAPITAL BUDCET CATEGORY & DETAIL & AFE & RECORDED \\
\hline
\end{tabular}

Location

26,700

Drilling Contractor Charge

0

Drilling Bits

2,000

Drilling Mud \& Chemicals

Power, Fue1 \& Water

23,000

Equipment Rentals

52,300

Specialized Drilled Service

112,500

Transportation - Personne1

3,000

Transportation, Equip. \& Sup.

10,000

Casing - Drilling

0

Unanticipated Major Dril1:rg Expense

95,000

Casing - Completion

0

Company Labor \& Supervision

62,000

Production Equipment

40,300

Completion Fluids

43,500

Completion Cost

454,900

Production Facilities

100,000

Miscellaneous

197,300

TOTALS

$\$ 1,222,500$

$\$$

Enton Industries of Houston. Inc.

Eaton Oporating Co.. Inc. 3100 Esilos

Housion, Toxas 77027

(713) 627.9764 
A.F.E. No

Dolo

$4-3-80$

DRILLING YELL COST ESTIMATE - SUPPORTING DATA

Shoot Ono of 5

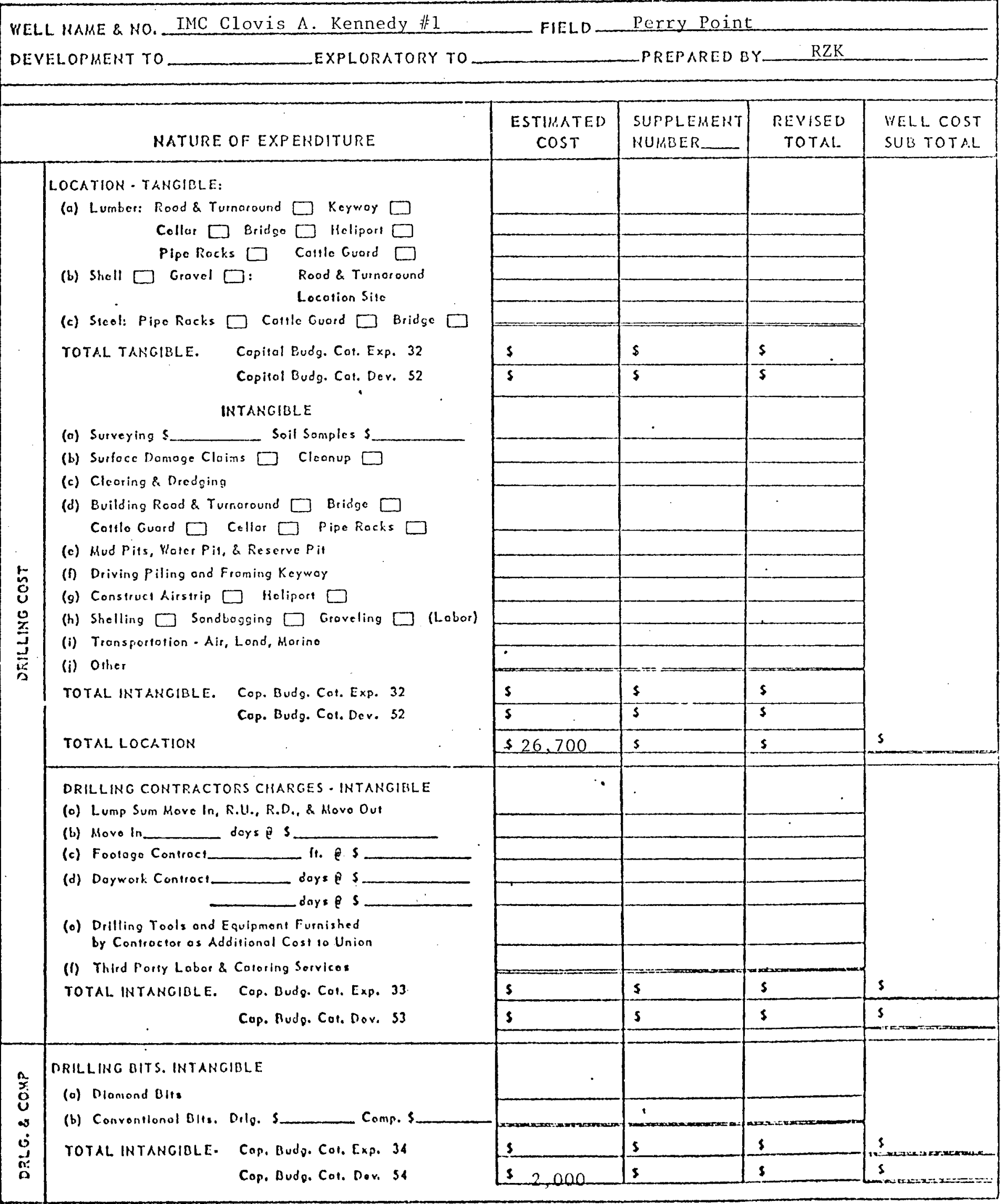


A. F. E. No.

\section{DRILLING WELL COST ESTIMATE - SUPPORTING DATA}

Shoos Two of__ 5

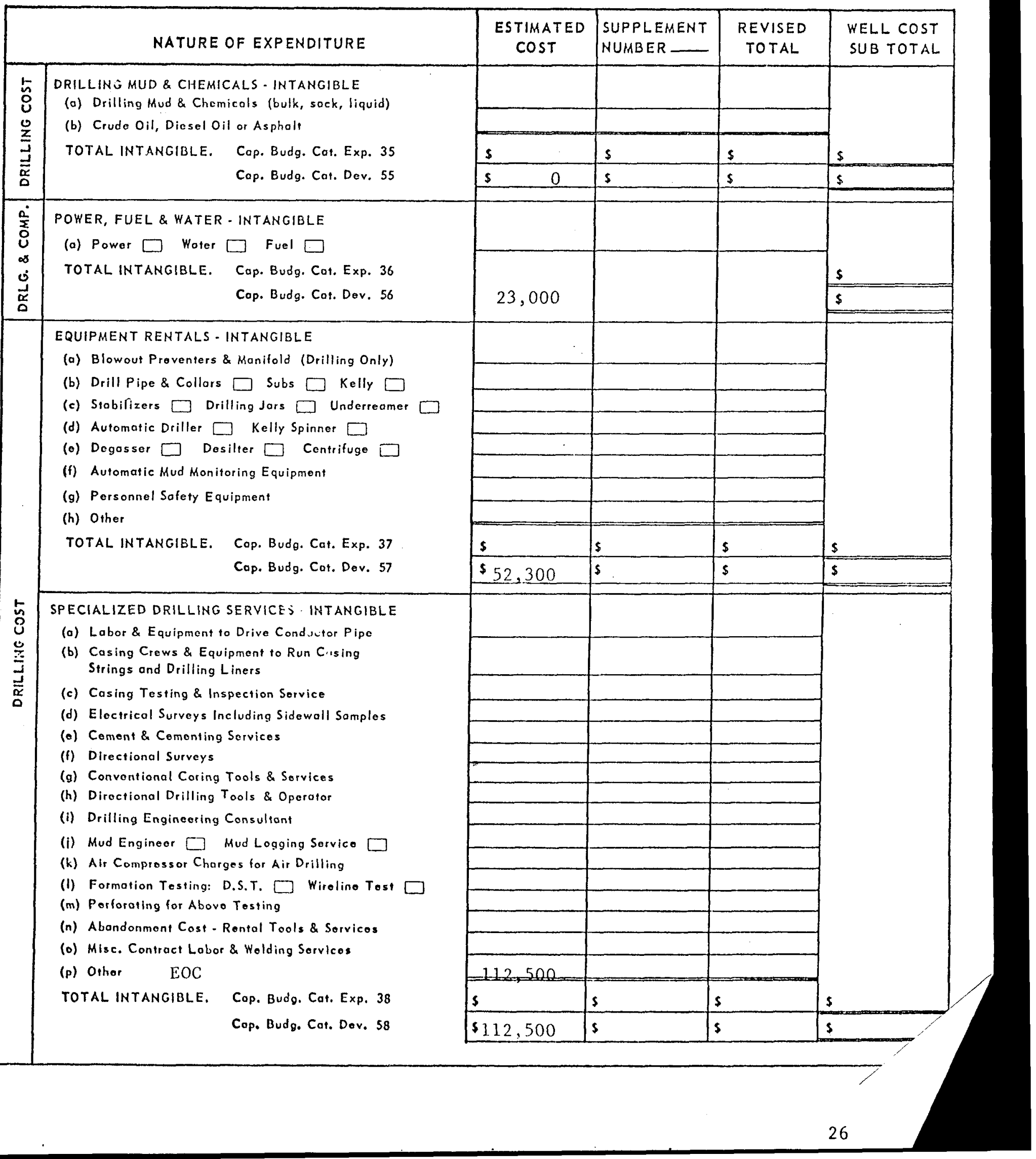


A.F.E. No.

\section{DRILLING WELL COST ESTIMATE - SUPPORTING DATA}

Shoot throe of 5

\section{NATURE OF EXPENDITURE}

TRANSPORTATION - PERSONNEL - INTANGIBLE
(a) Airplanes. Drilling \$
Completion $S$
(b) Helicopters - Drilling $\$$
Completions
(c) Crew Boots - Drilling $\$$
Completion \$
(d) Automobiles. Drilling $s$
Complation \$
(e) Standby Boat - Drilling $\$$
Completion \$

TOTAL INTANGIBLE. (Drilling) Cap. Budg. Cot. Exp. 39 (Drilling) Cap. Budg. Cat. Dev. 59

(Completion) Cap. Budg. Cat. Exp. 39

(Completion) Cap. Budg. Cot. Dev, 59

TRANSPORTATION - MATERIAL, EQUIPMENT \& SUPPLIES - INTANGIBLE.
(a) Airplanes - Drilling $\$$
Completion \$
(b) Helicopters - Drillings Completion $\$$
(c) Trucking - Drilling $\$$ Completion \$
(d) Cargo Vessels - Drilling $\$$
Completion \$
(e) Tugs - Drilling $\$$
Completion $\$$
(f) Barges - Drilling s
Completion $\$$

(g) Other Marine Equip. Drilling \$__ Complation $\$$

TOTAL INTANGIBLE. (Drilling) Cap. Budg. Cot. Exp. 40 (Drilling) Cap. Budg. Car. Dev, 60

(Completion) Cop. Budg. Car. Exp. 40

(Completion) Cap. Budg. Cat. Dev. 60

CASING - DRILLING - TANGIBLE
(a) __ Drive Pipe
ft. e $\$$
(b) __ Conductor
ft. es
(c) ____ Surface
fi. es
(d) _ Protection
if. $s$
(e) _L_ Liner
it. Q 5

(f) Liner Honging Equipment

(g) Casing Heads and Hangers

(h) Floating Equip., Serotchers \& Centralizors

(i) Deilling Spools

(i) Other

TOTAL TANGIBLE. Cop. Budg. Cot. Exp. 41

Cop. Budg. Cot. Dev. 61

UNANTICIPATED MAJOR DRILLING EXPENSE-INTANGIBLE

(a) Contract Daywork

doys $\$$

(b) Tools Lost in Holo

(c) Circulating Fluids \& Lost Circulation Matorial

(d) Fishing Tools, Equipment, Sorvices \& Expenses

(o) Transportotion. - Land, Marine \& Air

(f) Outsido Enginaoring or Consulting Exponso

(g) Diroctional Drilling Tools, Equipment \& Sorvicos

(h) Comenting Servicos \& Cement

(i) Pumping Sorvicos

(i) Othor

TOTAL INTANGIBLE. Cop. Budg. Cat. Exp. 46

Cap. Budg. Cal. Dov. 66

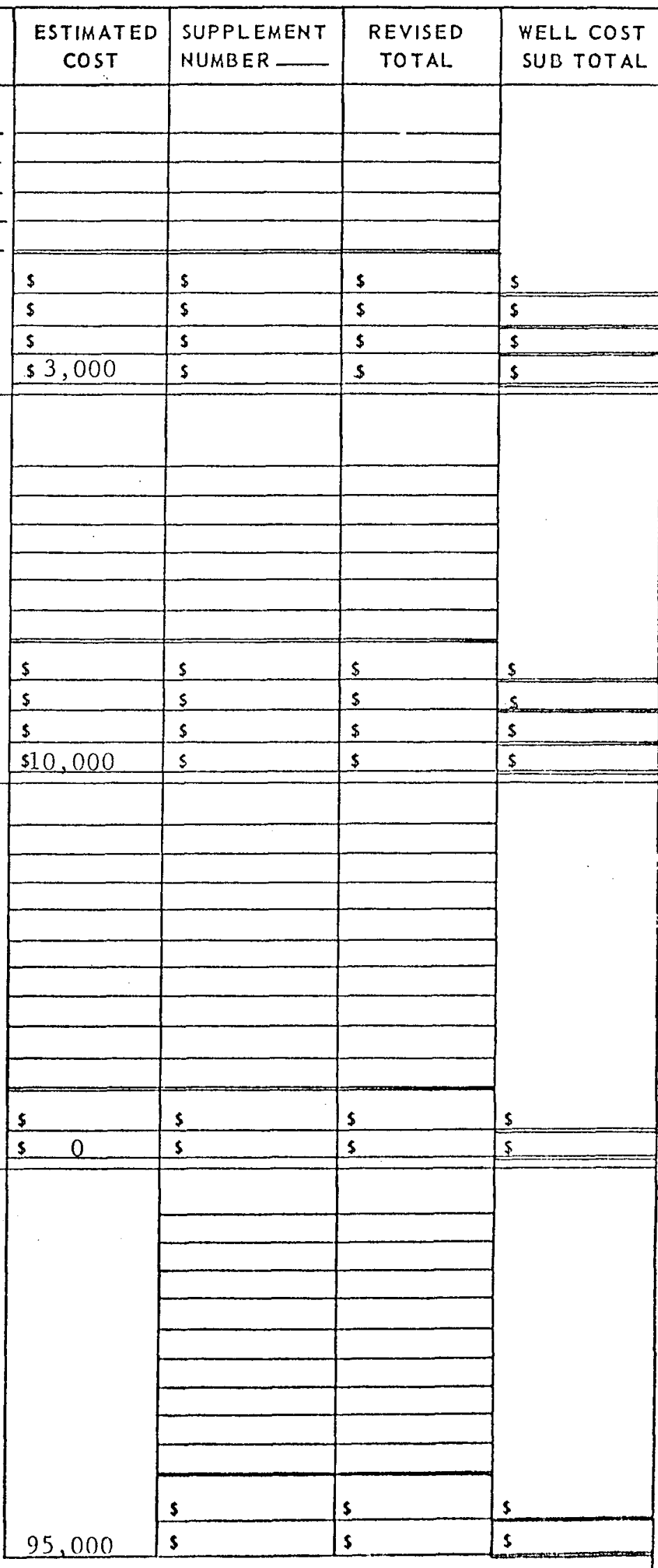


A. F.E. No.

DRILLING WELL COST ESTIMATE - SUPPORTING DATA

Shool four of 5

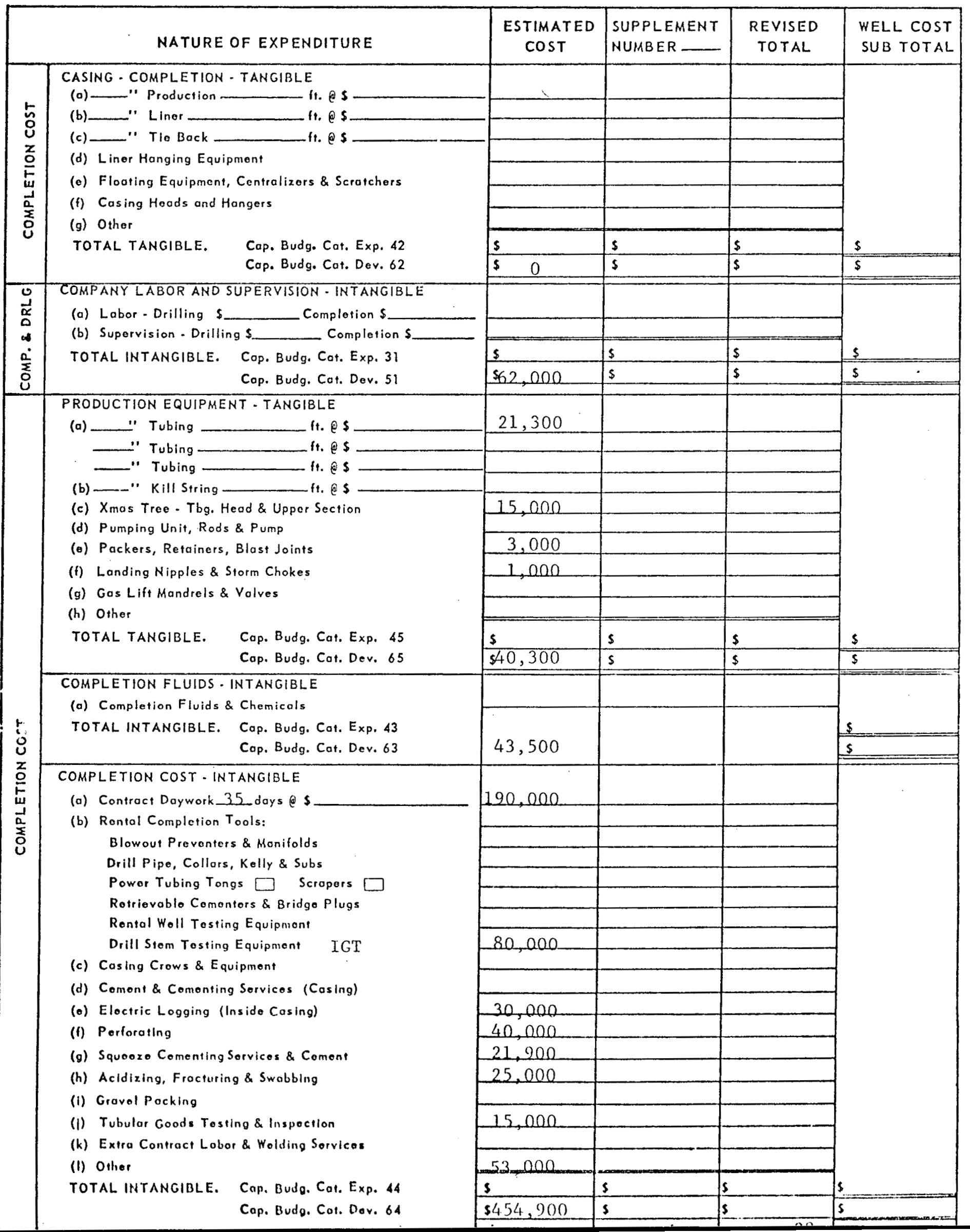


A.F.E. No.

DRILLING HELL COST ESTIMATE - SUPPORTING DATA

Shoot fivo

5

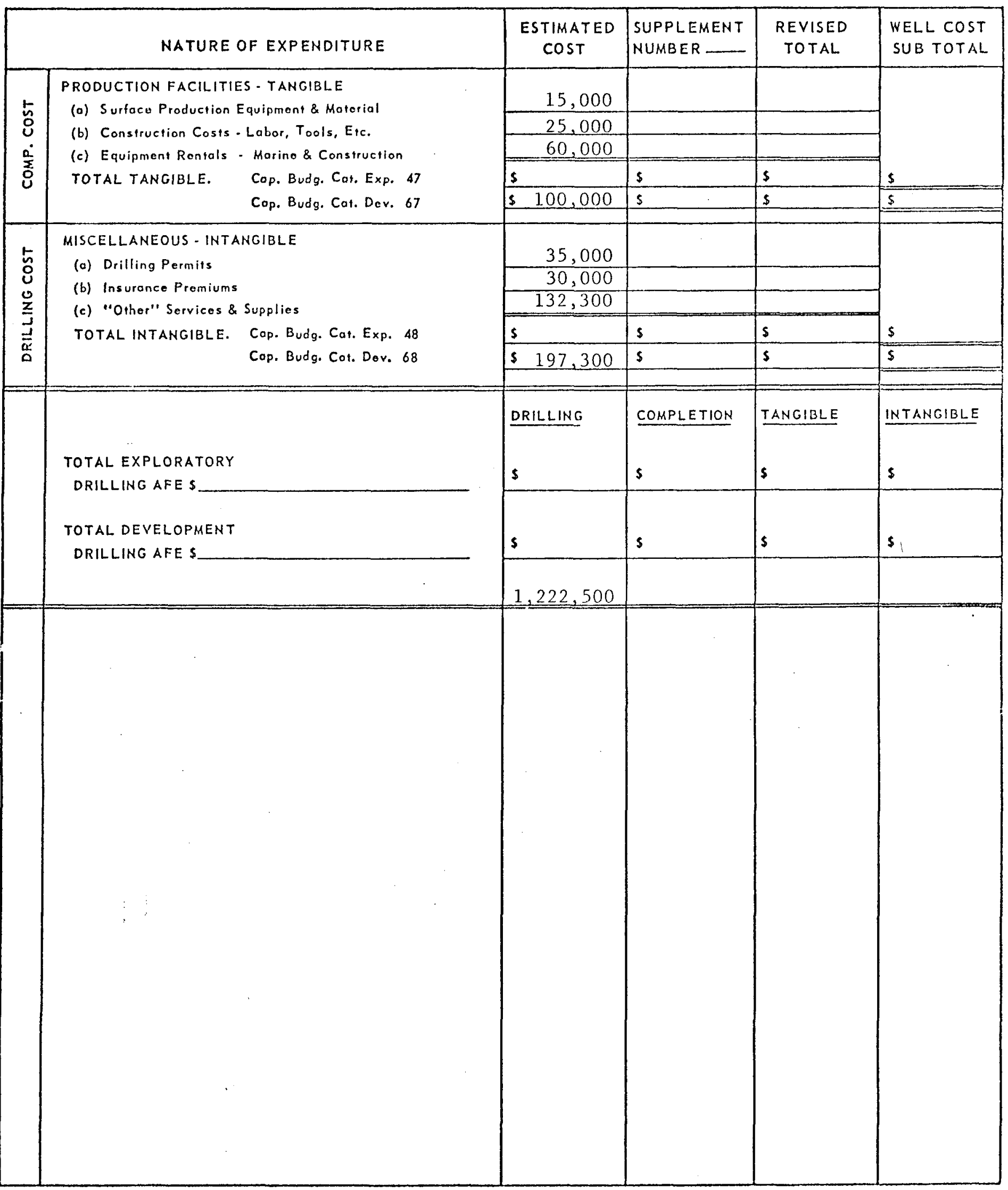




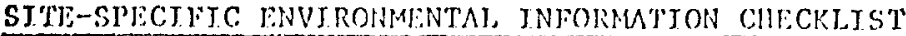

\section{GEOPRESSLRED-GEOTIM:RMAL. NELI TSST PROGRAM}

\section{WELL IMC EXPLORATION CLOVTS A KENNEDY 非}

LOCA'TON Vermilion Parish, Louisiana

\section{A. GENERAI,}

1. Is the proposed site located in the area covered by the "Gulf. Coast Programmatic Enviromental Assessment, Geothermel Weli Testing, the Frio Formation of Texas and Jouisiana, "October 1977? Yes $\mathrm{X}$ No If no, explain.

2. Has a Federal, state and/or local environmental assessment been conducted previously for the proposed test vell or other wells in the area? Yes No $\quad X$ If yes, provide a copy, if available.

3. Have all required permits, licenses, and/or agreements for proposed project been obtained? Yes No If no, explain. Cannot apply until Agreement with landowner finalized.

4. Dees the project site fall within the habitat of rare or endangered species? Yes No If yes, explain.

5. Are known archeological sites, historic sites, or natural landmarks within or visible from the sitc area? Yes No $\mathrm{X}$ If yes, explain.

6. Will expected continuous noise levels from sitc operations be 65 dBA or less at the nearest residence?

Yes $x$ No If no, explain.

Eaton Industries of Houston, Inc. Eaton Oporating Co., Inc. 3100 Edioe 


\section{B. SITE CONSTRUCTION}

1. Will additional land clearing be required for the test well (e.g., drill pad; road construction, mud reserve pits, pipeline)? Yes No If yes, describe.

2. Will additional land clearing be required for the disposal well (e.g., drill pad, reserve pits, utilities, road construction, pipeline)?

Yes No $\mathrm{x}$ If yes, describe.

3. Will the site and related roads be treated to minimize dust? Yes No $x$ If no, explain.

Use Boards - Marshland

4. Are portable sanitary facilities or an approved septic system to be used at the site? Yes $x$ No If no, explain.

5. Will liquid and solid wastes be disposed in accordance with local regulations? Yes $\mathrm{X}$ No__ If no, explain.

6. Will erosion control be required for excavated areas? Yes No If If yes, explain.

7. Will dredge spoil be deposited in swamp forest or marshland? Yes. No $\mathrm{X}$ If yes, explain. 
8. Upon completion of proposed test program, will the site be restored to as natural a condition as possible by regrading, filling, and resceding? Yes No If no, explain.

\section{c. WELL TESTTNG AND SAFETY}

1. Is fluid production from the well during testing expected to be 2 weeks or less in duration per formation? Yes $\mathrm{x}$ No If no, explain.

2. Is the total dissolved solids of the produced geopressure fluid expected to be $90,000 \mathrm{mg} / 1$ or less? Yes_ $\mathrm{X}$ If no, explain.

3. Is the volume of geopressure fluid to be produced and injected expected to be 300,000 barrels or less? Yes. No If no, explain.

4 Is the temperature of produced geopressured fluid expected to be $260^{\circ} \mathrm{C}$ or less? Yes_ $\mathrm{X}$ No If no, explain.

5. Will the gas content of the produced fluid be flared? Yes_ $\mathrm{X}$ No___ If no, explain.

6. Will blowout preventers rated to at least 10,000 psi be used? Yes_ $\mathrm{X}$ No__ If no, explain. 
7. Will production tubing rated to at least 20,000 psi, be used? Yes No__ $x$ If no, explain.

8. Can safety valves be operated from remote locations? Yes $\mathrm{X}$ No If no, explain.

9. Will the test tree be rated to at least 10,000 psi? Yes_ $\mathrm{X}$ No___ If no, explain.

10. Will a test well directional survey be conducted? Yes No $\mathrm{X}$ If yes, at what interval? , If no, explain.

11. Will a lined pond be used to hold all liquid effluents and production fluids that are not injected? Yes $\mathrm{X}$ No If no, explain.

12. Has an injection permit been obtained? Yes No $\mathrm{X}$ If no, explain. Cannot apply until Agreement with landowner finalized.

13. Will $\mathrm{H}_{2} \mathrm{~S}$ monitors be located on site? Yes No If no, eptain.

14. Will fire extinguishers be located on site? Yes $x$ No If no, explain. No history of $\mathrm{H}_{2} \mathrm{~S}$ in area.

15. Do contingency plans exist for evacuating personnel should a blowout occur or high levels of $\|_{2} S$ be detected? Yes $\mathrm{X}$ No If no, explain. 
16. Will high-pressure engineering and mud logging personnel be on site during production will drilling operations? Yes $\mathrm{X}$ No If no, explain.

Eaton Industries of Houston, Inc.

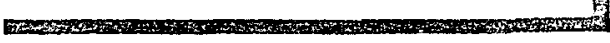
Eaton Operating Co., Inc. 3100 Edioe 